Critchlow, N., Moodie, C., Bauld, L., Bonner, A., \& Hastings, G. (2017). Awareness of, and participation with, usercreated alcohol promotion, and the association with higher-risk drinking in young adults. Cyberpsychology: Journal of Psychosocial Research on Cyberspace, 11(2), article 4. doi: 10.5817/CP2017-2-4

\title{
Awareness of, and participation with, user-created alcohol promotion, and the association with higher-risk drinking in young adults
}

\author{
Nathan Critchlow ${ }^{1}$, Crawford Moodie ${ }^{1}$, Linda Bauld ${ }^{1}$, Adrian Bonner ${ }^{2}$, \& Gerard Hastings ${ }^{1}$ \\ ${ }^{1}$ Institute for Social Marketing, University of Stirling, UK \\ ${ }^{2}$ School of Applied Social Sciences, University of Stirling, UK
}

\begin{abstract}
User-created alcohol promotion refers to the content distributed through new media which intends to promote consumption, but independent of commercial digital marketing. This study explores exposure to such usercreated alcohol promotion and the association with higher-risk drinking in a sample of young adults in the United Kingdom. An online cross-sectional survey with $18-25$ year olds $(N=405)$ was used to measure awareness of, and participation with, 11 forms of user-created alcohol promotion. Higher-risk drinking was measured through the Alcohol Use Disorders Identification Test - Consumption (AUDIT-C). On average, participants were aware of 7.48 user-created alcohol promotion channels and had participated with 4.36. A hierarchical logistic regression highlighted a positive association between exposure to user-created alcohol promotion and higherrisk consumption, with participation $(A O R=1.64)$ having a stronger association with higher-risk consumption than awareness $(A O R=1.19)$. The results suggest that young adults are aware of, and participating with, a cumulative range of user-created alcohol promotion, both within and beyond social media. Further research is required to understand whether this association with higher-risk drinking is causal, the links between usercreated alcohol promotion and commercial marketing, and the wider utility of user-created content to influence health behaviours in young adults.
\end{abstract}

Keywords: Alcohol; users-created promotion; consumption; higher-risk drinking; young adults

\section{Introduction}

Understanding what factors drive higher-risk alcohol consumption is crucial given the negative consequences for both the drinker and for others (Gell, Ally, Buykx, Hope, \& Meier, 2015; World Health Organisation, 2014). It is particularly important for young adults, as the global prevalence of heavy episodic drinking among this age group (11.7\%) is higher than the rest of the adult population (7.5\%) (World Health Organisation, 2014). One factor found to be associated with higher-risk drinking among young adults is exposure to alcohol-related media (Atkinson, Elliot, Bellis, \& Sumnall, 2011; Grube, 2004). Until recently, however, research has typically overlooked the role of digital media, even though young adults report higher rates of internet use than most other age groups (Statistica, 2015). Nevertheless, formative research has begun to explore whether there is association between drinking behaviour and the alcohol-related content seen online. This research is divided into two categories: (1) research exploring commercial digital alcohol marketing (Lobstein, Landon, Thornton, \& Jernigan, 2016), and (2) research exploring the content created by other internet users. Research into the latter, however, has mostly focused on personal or peer content on social networking websites (see Moreno, D'Angelo, \& Whitehill, 2016, and Westgate \& Holliday, 2016). This study therefore investigates exposure to a broader range of user-created alcohol promotion, both within and beyond social networking websites, and explores what association (if any) this has with higher-risk drinking in young adults. 


\section{User-Generated Content}

Throughout most of the $20^{\text {th }}$ century the design of traditional media channels, such as television and print, meant that audiences were passive observers who had little power to influence content (Jenkins, 2006). Web 2.0 has instead created a culture where internet users can participate in how content is created, predominantly through social media and media-sharing websites which are designed for this purpose (Kaplan \& Haenlein, 2010; Livingstone, 2003; van Dijck, 2009, 2012). This content-creation revolution is characterised by the many not the few, with half of the estimated three billion internet users worldwide (Internet Society, 2015) now members of Facebook (Facebook, 2015), for example. Further highlighting the growth of media-sharing, it is estimated that 300 hours of video are uploaded to YouTube every minute (Statistics Brain, 2015) and approximately 80 million photos are uploaded to Instagram every day (Instagram, 2015). In the UK, that 16-24 year olds spend more time online per week than the rest of the adult population, and report participation in a broad range of online activities, further suggests that it is young adults who take an active role in content creation (OFCOM, 2015a, 2015b).

\section{User-Created Alcohol Promotion: Definition, Assumptions, and Relationship to Marketing}

Previous research has suggested that the online content created by other internet users may promote or reflect health risk behaviours offline. This includes drug use (Norman, Grace, \& Lloyd, 2014), smoking (van Hoof, Bekkers, \& van Vuuren, 2014), sexual risk (Kletteke, Hallford, \& Mellor, 2014), violence (Zonfrillo, Arbogast, \& Fien, 2014), self-harm (Avery, Rae, Summit, \& Kahn, 2016), and multiple health-risk behaviours (Moreno, Parks, \& Richardson, 2007). One relationship which is frequently referenced is a link between user-created content and alcohol consumption in young people (Gupta, Pettigrew, Lam, \& Tait, 2016; Moreno et al., 2016; Ridout 2016; Westgate, \& Holliday, 2016). Such user-created alcohol promotion is important as, distinct from commercial marketing, it is not bound to adhere to regulations for responsible promotion (see Committee of Advertising Practitioners, 2015, for guidelines in the UK) and young people consider peer messages to be an influential and accurate reflection of offline behaviour (Atkinson, Ross, Begley, \& Sumnall, 2014; Moreno et al., 2009). Despite increased research interest, there is still no explicit definition of the alcohol promotion created by users. Therefore, building on the criteria used to define more general user-generated content (McKenzie et al., 2012; McNally et al., 2012; Organisation for Economic Co-Operation and Development, 2007), in this study we defined user-created alcohol promotion as the content distributed through new media which intends to promote alcohol consumption, but largely independent of commercial marketing.

There are two assumptions to this definition which warrant discussion. The first is that user-created alcohol promotion and user-generated branding are different. There are similarities between the two, including user-led creation, requirement for publication, and need for creative effort (Arnhold, 2010). User-created alcohol promotion, however, does not consider personal representation of an alcohol brand to be an underlying motive for creation, whereas user-generated branding does. A Facebook group focused on promoting drunkenness, for example, would meet the definition even if an alcohol brand is featured (e.g. in a photo). A fan page designed to pay homage to a specific alcohol brand, however, would not. Second, the definition does not exclude content created by users who have a professional skillset or receive a commercial or monetary return, provided the content does not directly contribute to commercial alcohol marketing goals. As such, a quiz about alcohol on a social entertainment website would be allowed (see Perry, 2015, for example), however articles sponsored by an alcohol brand on the same website would not (see Captain Morgan, 2015, for example).

Content analysis research has reported that user-created alcohol promotion appears across a range of new media. Documented examples include textual and visual references on social networking profiles (Atkinson et al., 2014; Ridout, Campbell, \& Ellis, 2012; Fournier \& Clarke, 2011), groups and pages on social media (Mart, Mergendoller, \& Simon, 2009), smartphone apps (Weaver, Horyniak, Jenkinson, Dietz, \& Lim, 2013), YouTube videos (Primack, Colditz, Pang, \& Jackson, 2015), Twitter content (Cavazos-Rehg, Krauss, Sowles, \& Bierut, 2015), forums (Parder \& Vihalemm, 2015), and online quizzes (Griffiths \& Casswell, 2010). NekNominate provides a high-profile example which shows that user-created alcohol promotion can also appear across multiple channels. NekNominate was an online drinking game in which an individual posted a video of themselves consuming an alcoholic drink before nominating a peer, by tagging them on social media, to continue the practice within the next 24 hours (Wombacher, Reno, \& Veil, 2016; Zonfrillo \& Osterhoudt, 2014). The game not 
only generated content from users, but also produced public fan pages (Neknominate, n.d.) and video compilations of individuals taking part (Viral Videos Today, 2014).

Commercial digital alcohol marketing and user-created alcohol promotion co-exist closely in the same online spaces (Atkinson et al., 2014; Griffiths \& Casswell, 2010; Moreno et al., 2016; Westgate \& Holliday, 2016). This paper therefore also provides a model to detail the relationship between the two and to explain how public and private realms are merged through digital media (Figure 1). The model suggests that digital marketing and usercreated alcohol promotion are separate entities which are produced by stakeholders who largely have contrasting motivations for creating content (e.g. social and financial). This model also suggests that some usercreated alcohol promotion intends to promote drinking without explicitly promoting a brand (e.g. photos of peers), while some marketing does not require users to co-produce content (e.g. on-demand television adverts). The model suggests, however, that there are instances where users may choose to be involved in the marketing process or where marketers may realise the potential of user-created promotion to boost marketing goals. For example, the popular video-blogger 'Tipsy Bartender' has previously worked in collaboration with alcohol producer Diageo (StreamDaily, 2014), while user-comments on social media are considered an influential way of extending and enhancing marketing messages (Carah, 2014). For clarity, this study only focuses on user-created alcohol promotion. It does, however, remain sensitive to the broader online context in which such content features and the other forms of content which may provide confounding influence.

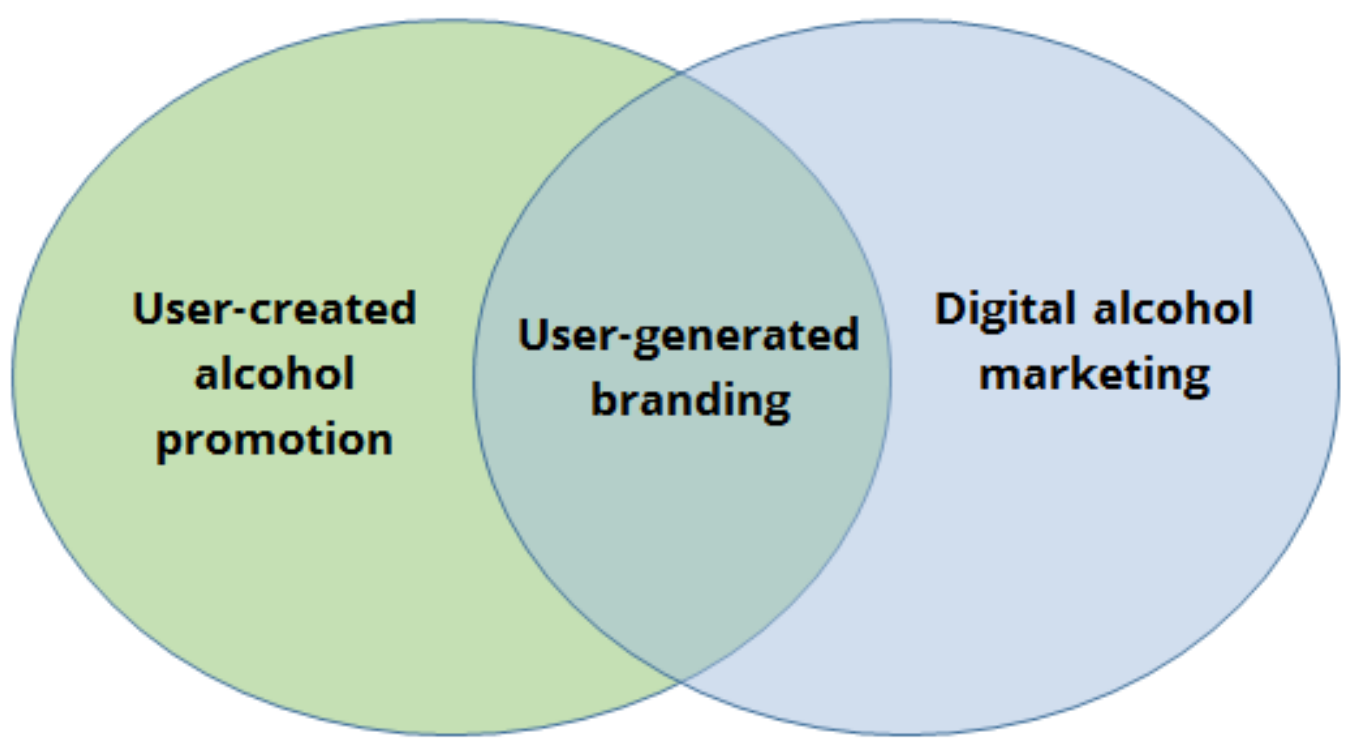

Figure 1. The relationship between digital alcohol marketing and user-created promotion.

\section{User-Created Alcohol Promotion and Alcohol Consumption in Young People}

Research which has explored exposure to user-created alcohol promotion, and the association with consumption in young adults, is divided into four categories: (1) cross-sectional surveys, (2) experimental designs, (3) longitudinal surveys, and (4) focus groups and interviews. Cross-sectional surveys report that young adults are aware of, and have participated with, a range user-created alcohol promotion. For instance, 32\% report that they have uploaded pictures of themselves consuming alcohol to social media (Morgan, Snelson, \& Elison-Bowers, 2010), 56\% report that they have uploaded pictures of their peers drinking (Glassman, 2012), 83\% report that they are aware of pictures posted by others which document peer consumption (Morgan et al., 2010), 38\% report that they have posted on Twitter about alcohol or followed an account which promotes drinking (Cabrera-Nguyen, Cavozos-Rehg, Krauss, Bierut, \& Moreno, 2016), and 54\% report that they took part in the Neknominate drinking game (Moss et al., 2015). Longitudinal surveys and experimental designs have further suggested that awareness of, and participation with, user-created alcohol promotion is associated with willingness to drink, frequency of consumption, and higher-risk drinking (Boyle, LaBrie, Froidevaux, \& Witkovic, 2016; D’Angelo, Kerr, \& Moreno, 2014; Litt \& Stock, 2011; Marczinski et al., 2016; Pumper \& Moreno, 2013). Focus groups and interviews also suggest that the relationship is more complex than implied by an exposure equals consumption hypothesis. Not only are young adults willing to participate with user-created alcohol promotion, 
but doing has become a valued activity which provides rewards in terms of social and cultural capital (Atkinson et al., 2014; Lyons et al., 2014). It is also suggested the practice of engaging with such promotion is a strategically managed process, with the end product being content that presents consumption, and the associated outcomes, as highly desirable and positive (Niland, Lyons, Goodwin, \& Hutton, 2014).

\section{Current Study}

Most research which has investigated user-created alcohol promotion has typically had a narrow focus, and concentrated mainly on individual or peer activity on social networking websites. Research is yet to explore whether young adults are aware of, and participate with, a broader range of user-created alcohol promotion beyond social media, or whether cumulative exposure across channels has a stronger association with consumption than individual channels; a hypothesis supported in alcohol marketing research (Gordon, MacKintosh, \& Moodie, 2010; Lin, Casswell, You, \& Huckle, 2012). This study responds to these gaps by exploring awareness of, and participation with, user-created promotion, both within and beyond social media, and considering what association this has with higher-risk consumption in young adults.

\section{Methods}

\section{Design and Sample}

An online, cross-sectional survey was conducted with 18-25 year olds in the UK, most of whom were students in undergraduate education $(n=405)$. Young adults were chosen as the sample given the high rates of higher-risk drinking and internet use that are reported in this age group in the UK (OFCOM, 2015a; Office for National Statistics, 2015a, 2015b). Responses were collected in two six month waves, November 2013-April 2014 and February 2015-July 2015. A convenience sample was recruited through adverts posted on: (1) the 'Surveys and Research' section of www.thestudentroom.co.uk, a large UK-based community website for school and university students; (2) an internal university website which allowed undergraduate psychology students, who had not covered content related to the aims of the study as part of their course, to participate in exchange for academic credits required for a research methods module; and (3) an advert shared on Facebook.

\section{Measures}

A range of measures were included in the survey including: demographic information; internet use and access; awareness of, and participation with, user-generated alcohol promotion; and higher-risk alcohol consumption.

Demographics. Age, gender, ethnicity, and religious denomination were measured.

Internet use and access. To measure frequency of internet use participants were asked 'How often do you use the internet?' Responses were given on a nine-point scale ( 1 = Never -9 = Everyday). To measure duration of internet use participants were asked: 'On average, how long do you spend on the internet per day?' Responses were given on a nine-point scale $(1=1$ don't use the internet $-9=$ Nine or more hours). To measure how participants accessed the internet they were asked "What devices do you use, or have previously used, to access the internet?" Participants were presented with a list of five devices; (1) shared computer, (2) personal computer, (3) tablet, (4) smartphone, and (5) school, university, or work computer. Participants used a dichotomous response option to indicate (Yes/No).

Awareness of, and participation in, user-created alcohol promotion. Awareness of, and participation with, user-created alcohol promotion was assessed for 11 channels: (1) social media status updates, (2) non-fictional photos (e.g. photos of real peers or family drinking alcohol), (3) fictional photos (e.g. fictional memes or cartoon images), (4) multimedia or instant messaging (e.g. snapchat), (5) games, (6) fan pages or public groups, (7) smartphone apps, (8) forums, (9) quizzes, (10) blogs or microblogs, and (11) viral or shared videos. For each, participants were shown a visual example and asked to indicate if they had seen alcohol promoted through that channel (Yes/No), and whether they had participated with promotion though that channel (Yes/No). Responses were summed to create a cumulative score for both awareness and participation (0-11). The question design and 
phrasing was based on measures previously used to assess awareness of, and participation with, commercial digital alcohol marketing (Gordon et al., 2010; Lin et al., 2012). A Cronbach's Alpha indicated acceptable internal consistency for both the awareness $(\alpha=.70)$ and participation subscales $(\alpha=.69)$

As user-created alcohol promotion comes in a variety of styles and designs, the phrasing of each question was tailored to be specific to each channel, and the keywords were emphasised in bold to make it clear to the participant when they were being asked about awareness and participation (Figure 2). For each question participants were reminded that the visual was only an example and to consider others they recalled. Prior to completing this section, the participants were informed 'The following questions measure the ways you have seen alcohol, or the effects of alcohol, displayed or discussed online by others. By others we mean content made by friends, family, celebrities, or other individuals not related to, or about, an alcohol brand'. This statement was intended to mitigate any confusion over user-created alcohol promotion and user-generated branding (e.g. fan photos), digital alcohol marketing (e.g. viral videos), or content co-created between marketers and users.

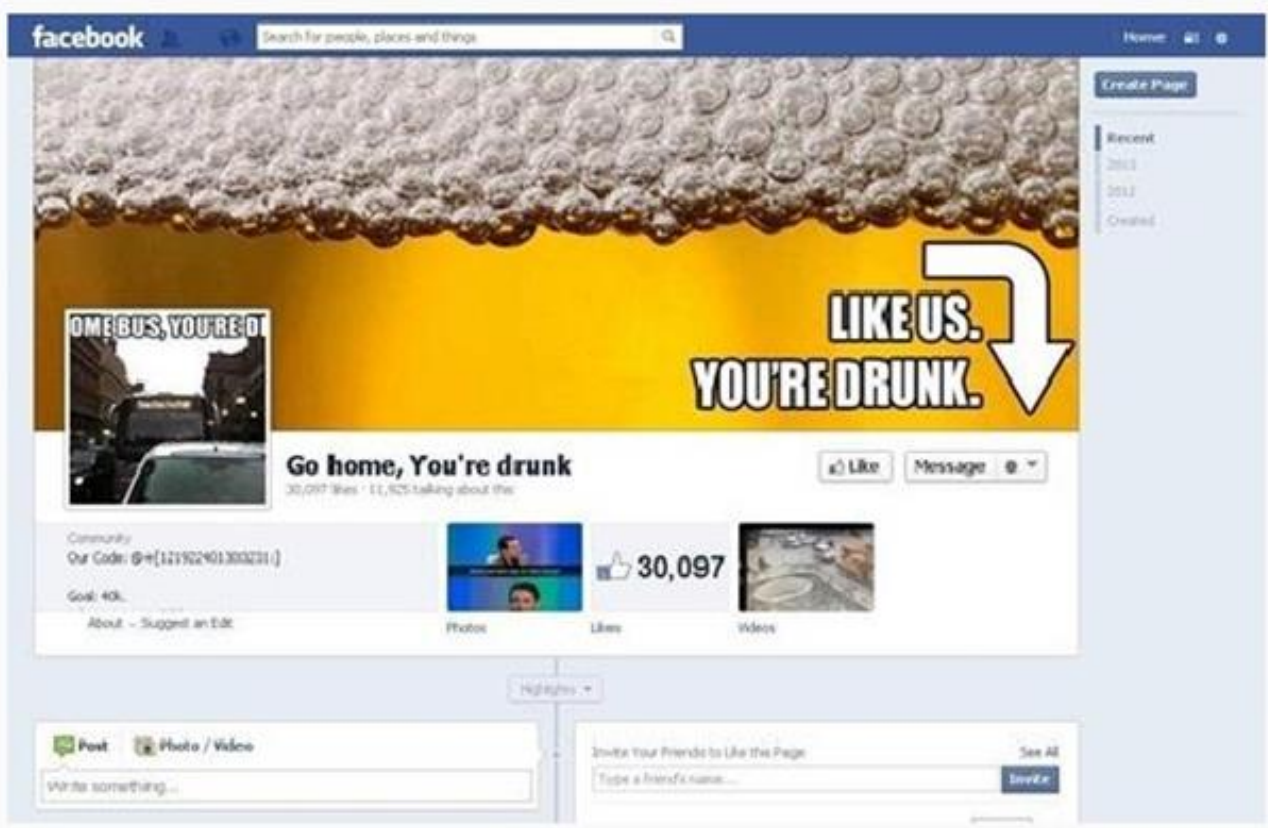

\section{Groups or fan pages on Facebook (or other social networking sites) about alcohol or the effects of drinking alcohol? (e.g. 'Go home, you're drunk' or other parody accounts).}

\begin{tabular}{l|l|l} 
& Yes \\
\hline Have you seen groups or fan \\
pages on Facebook about \\
drinking alcohol, or its effects? \\
(e.g. 'Go Home You're Drunk)?
\end{tabular}

Figure 2. Example of grid for measuring awareness of, and participation with, user-created alcohol promotion.

Higher-risk consumption. Higher-risk drinking was measured using the Alcohol Use Disorders Identification Test - Consumption (AUDIT-C). This three-item screening tool, which has been validated in the UK (Foxcroft, Smith, Thomas, \& Howcutt, 2015), assessed three types of behaviour: (1) frequency of consumption, (2) units drunk on a typical drinking occasion, and (3) frequency of high episodic drinking. Responses were provided on a five-point scale, scored 0-4, with the answers on each scale relative to frequency (Never - 4+ times a week), units 
drunk (1-2 units - 10+ units), and frequency of high episodic drinking (Never - Daily/Almost Daily). A diagram depicting the unit content of alcoholic drinks, such as a $175 \mathrm{ml}$ glass of wine or pint of regular beer/lager/cider, was included to assist in estimating the units drunk on a typical drinking occasion. Responses were summed to create a cumulative score (0-12). Research has suggested several cut-offs for identifying higher-risk drinking using the AUDIT-C (Barry, Chaney, Stellefson, \& Dodd, 2015; Dawson, Smith, Saha, Rubinsky, \& Grant, 2012; DeMartini \& Carey, 2012). This study used a cut-off score of $>5$, as specified by the National Health Service Health Check Programme: Best Practice Guidance (Department of Health, 2013). A Cronbach's Alpha indicated that the AUDIT-C had acceptable internal consistency $(\alpha=.81)$.

\section{Procedure}

The self-report questionnaire was designed and hosted on Qualtrics (www.qualtrics.com), a full-featured, webbased tool used to create and conduct online surveys. Advertisements highlighting the aims and methods of the study were placed on the 'Surveys and Research' section of www.thestudentroom.co.uk. The adverts remained there throughout the two recruitment periods and were refreshed once a fortnight. An advert was also uploaded to the internal student recruitment website and posted on social networking site, Facebook, by the lead investigator. Those who met the inclusion criteria (18-25 years old and living in the UK) were invited to click on a hyperlink, which directed their web-browser to the online questionnaire. Prior to survey onset participants were informed of the study aims, incentive, the anonymity of data, the voluntary nature of the study, and the ability to withdraw at any point. Participants were asked to confirm they met the age criteria and consented to take part (Yes/No). The average completion time for the questionnaire was 20 minutes. After questionnaire completion, a debriefing page was displayed that asked participants whether they would like to entered a ballot to win one-of-five $£ 10$ vouchers for an e-retailer (Yes/No) as a thank you for participation. Those who wished to enter were redirected to a separate questionnaire to provide an e-mail address which registered their place. Those who did not were directed to a page which confirmed the questionnaire was finished. Ethical approval was obtained from the University of Roehampton's ethics board (PSYC 13/097) and Salvation Army's Territorial Health Ethics Advisory Committee ( $4^{\text {th }}$ October 2013).

\section{Data Analysis}

The data was analysed using SPSS version 21. Cases in which: (1) no age was specified, (2) the respondent was not aged 18-25 years old, and (3) the IP address of the respondent was outside the UK, were removed. All responses were screened for contradictory answers using cross-tabulation tables. Responses in which participation with user-created alcohol promotion was indicated, yet awareness of the same channel was not, were removed. Frequency tables and descriptive statistics were used to explore awareness of, and participation with, each example of user-created promotion. A bootstrapped paired samples $t$-test was conducted to examine the differences between cumulative awareness and participation.

A hierarchical logistic regression, based on 2,000 bootstrapped samples, was conducted with awareness of, and participation with, user-created promotion as the independent variables and indication of higher-risk drinking the dependent variable (Yes/No). Demographic variables (age, gender, religious beliefs and ethnicity) were entered at step one, with all but age categorical. Female was used as the baseline for gender. Ethnicity was coded into binary categories, 'White British' and 'Other', with the latter used as the baseline. Religion was also coded into binary categories (Yes/No), with 'Yes' used as the baseline. These control variables were chosen as they are factors known to be associated with different levels of personal alcohol use in the UK, for example those from a White British background are reported to consume more than those of other ethnicities (NewburyBirch et al., 2009; Office for National Statistics, 2016). Cumulative awareness of user-created promotion was entered at step two, and cumulative participation with user-created promotion at step three. All variables were entered using a forced entry method. 


\section{Results}

\section{Sample Characteristics and Internet Use}

The sample $(N=405)$ had an average age of $21.15(S D=2.22)$. The majority were female $(72 \%)$, identified as White British (66\%), and indicated that they were not religious (61\%). Almost the entire sample used the internet every day (99\%), and the majority spent two-four hours online each day (65\%). Participants had accessed the internet through a range of devices, with personal computers (97\%) and mobile or smartphones (96\%) reported most (Table 1).

Table 1. Sample Characteristics and Internet Use.

\begin{tabular}{|c|c|c|}
\hline Variable & $\%$ & $n$ \\
\hline \multicolumn{3}{|l|}{ Gender } \\
\hline Male & 28 & 113 \\
\hline Female & 72 & 292 \\
\hline \multicolumn{3}{|l|}{ Ethnicity } \\
\hline White British & 66 & 267 \\
\hline Other & 34 & 138 \\
\hline \multicolumn{3}{|l|}{ Religion } \\
\hline No religion & 62 & 250 \\
\hline Yes & 38 & 155 \\
\hline \multicolumn{3}{|l|}{ Internet use - Frequency } \\
\hline Everyday & 99 & 402 \\
\hline Four or more times a week & $>1$ & 3 \\
\hline \multicolumn{3}{|l|}{ Internet use - Average duration per day } \\
\hline One hour or less & 15 & 58 \\
\hline Between two and four hours & 65 & 264 \\
\hline Five or more hours & 20 & 83 \\
\hline \multicolumn{3}{|l|}{ Device use } \\
\hline Personal computer & 97 & 392 \\
\hline Mobile phone & 96 & 388 \\
\hline Work, university, or school computer & 87 & 354 \\
\hline Tablet & 64 & 259 \\
\hline Shared computer & 43 & 173 \\
\hline \multicolumn{3}{|l|}{ Higher-risk drinking ( $\geq 5$ on AUDIT-C) } \\
\hline Positive & 54 & 221 \\
\hline Negative & 46 & 184 \\
\hline
\end{tabular}

\section{Awareness of, and Participation with, User-Created Alcohol Promotion}

On average, participants were aware of 7.48 of the 11 user-created alcohol promotion channels $(S D=2.22$, range $30-99 \%)$ and had participated with $4.36(S D=2.41$, range 6-77\%) (Table 2). A paired samples $t$-test indicated that cumulative awareness of user-created alcohol promotion was significantly greater than participation, $t(404)=$ $30.68, p<.001, d=3.05$.

\section{Association Between User-Created Alcohol Promotion and High-Risk Drinking}

Over half the sample scored positive for high-risk drinking $(54 \%, n=221$ ) ( $\geq 5$ on the AUDIT-C). A hierarchical logistic regression model was used to analyse the association between user-created alcohol promotion and higher-risk consumption. The first step of the model examined the association between higher-risk drinking and the demographic control variables. This step was significant, $\chi^{2}(4)=33.70, p<.001$, accounted for $11 \%$ of the variance, and classified higher-risk drinking status with 62.7\% accuracy (Table 3). Being male increased the odds of being a higher-risk drinker by $114 \%$ (Adjusted odds ratio $=2.14, p<.001$ ) and being white British increased the 
odds of being a higher-risk drinker by $156 \%(\mathrm{AOR}=2.56, p<.001)$. Neither religious denomination (AOR $=1.22, p$ $=.35)$ nor age $(A O R=1.06, p=.20)$ had a significant association with higher-risk drinking.

Table 2. Awareness of, and Participation with, User-Created Alcohol Promotion.

\begin{tabular}{lcccc}
\hline & \multicolumn{2}{c}{ Awareness } & \multicolumn{2}{c}{ Participation } \\
Channel & $\%$ & $n$ & $\%$ & $n$ \\
\hline Non-fictional photos (e.g. friends and peers) & & & 401 & 77 \\
Fictional photos (e.g. memes, cartoons) & 99 & 310 \\
Social media posts & 94 & 381 & 60 & 242 \\
Shared and viral videos & 94 & 381 & 58 & 233 \\
Multimedia instant messaging & 84 & 341 & 68 & 275 \\
Social networking pages/groups & 83 & 335 & 65 & 264 \\
Microblogging & 67 & 273 & 25 & 101 \\
Quizzes & 60 & 243 & 23 & 93 \\
Smartphone applications & 53 & 213 & 23 & 94 \\
Forums & 48 & 193 & 16 & 66 \\
Games & 36 & 147 & 6 & 26 \\
Cumulative mean (SD) & 30 & 122 & 15 & 62 \\
\hline
\end{tabular}

Note: Cumulative mean refers to the average number of the 11 user-created alcohol promotion channels that each participant was aware of or participating with.

The second step of the regression model examined the association between awareness of user-created alcohol promotion and higher-risk drinking. This step was significant, $\chi^{2}(1)=11.70, p<.001$, raised the variance explained to $14 \%\left({ }^{\Delta} R^{2}=.035\right)$, and increased the classification accuracy to $63 \%$. Awareness of each form of usercreated alcohol promotion increased the odds of being classified as a higher-risk drinker by $19 \%$ ( $A O R=1.19, p<$ $.001)$. Being male $(A O R=1.93, p<.01)$ and of white British ethnicity $(A O R=2.34, p<.001)$ also retained a significant association with higher-risk drinking.

The final step of the regression model examined the association between participation with user-created alcohol promotion and higher-risk drinking. This step was significant, $\chi^{2}(1)=62.21, p<.001$, raised the variance of higher-risk drinking explained to $31 \%\left({ }^{\Delta} R^{2}=.17\right)$, and increased the classification accuracy to $72.1 \%$. Participation with each form of user-created alcohol promotion increased the odds of being classified as being a higher-risk drinker by $64 \%(\mathrm{AOR}=1.64, p<.001)$. Being male $(\mathrm{AOR}=1.84, p<.05)$ and white British $(\mathrm{AOR}=1.90, p<.01)$ retained a significant association with higher-risk drinking. In step three, however, greater awareness of usercreated alcohol promotion did not significantly increase the odds of being a higher-risk drinker $(\mathrm{AOR}=0.89, p=$ .08). This suggested that participation mostly accounted for the association of awareness of user-created alcohol promotion on higher-risk drinking.

\section{Discussion}

The results are consistent with previous research which has suggested that young adults are aware of, and participating with, user-created alcohol promotion, and that such exposure is associated with alcohol consumption and higher-risk drinking (Gupta et al., 2016; Moreno et al., 2016; Ridout, 2016; Westgate \& Holliday, 2016). The results extend understanding by suggesting that user-created alcohol promotion which exists beyond social networking websites is also successful in reaching young adults and encouraging them to participate. This includes microblogging, viral videos, smartphone apps, online games, and internet forums.

Nevertheless, that participants were most exposed to user-created alcohol promotion on social networking websites supports why such content has featured prominently in exploratory content research (Atkinson et al., 2014; Fournier \& Clarke, 2011), experimental studies (Litt \& Stock, 2011), longitudinal surveys (Boyle et al., 2016), and qualitative research (Lyons et al., 2014). That the reported awareness of, and participation with, user-created alcohol promotion on social networking websites was higher than previous surveys (e.g. Cabrera-Nguyen et al., 2016; Glassman et al., 2012; Morgan et al., 2010) may reflect the detailed phrasing of each question or the visual examples used to stimulate cue-reactivity (McCraken \& Macklin, 1998). It is also possible that awareness and 
participation may be greater in young people in the UK compared to the USA, where most previous research has been conducted.

Table 3. Logistic Regression of Association Between User-Created Alcohol Promotion and Higher-Risk Drinking.

\begin{tabular}{|c|c|c|c|c|c|}
\hline \multirow{2}{*}{$\begin{array}{l}\text { Variable } \\
\text { Block } 1\end{array}$} & \multirow[t]{2}{*}{$n$} & \multirow[t]{2}{*}{ Odds ratio } & \multicolumn{2}{|c|}{$95 \% \mathrm{Cl}$ for odds ratio } & \multirow[t]{2}{*}{$p^{1}$} \\
\hline & & & & & \\
\hline Age & 405 & 1.06 & 0.97 & 1.16 & n.s \\
\hline \multicolumn{6}{|l|}{ Gender } \\
\hline Female & 292 & 1.00 & & & \\
\hline Male & 113 & 2.14 & 1.34 & 3.44 & $<.001$ \\
\hline \multicolumn{6}{|l|}{ Ethnicity } \\
\hline Other & 138 & 1.00 & & & \\
\hline White British & 267 & 2.56 & 1.65 & 3.40 & $<.001$ \\
\hline \multicolumn{6}{|l|}{ Religion } \\
\hline Yes & 155 & 1.00 & & & \\
\hline No & 250 & 1.22 & 0.80 & 1.88 & n.s \\
\hline \multicolumn{6}{|l|}{ Block 2} \\
\hline Awareness of user-created promotion (0-11) & 405 & 1.19 & 1.07 & 1.32 & $<.001$ \\
\hline \multicolumn{6}{|l|}{ Block 3} \\
\hline Participation with user-created promotion (0-11) & 405 & 1.64 & 1.43 & 1.88 & $<.001$ \\
\hline Model summary at each block & $\chi^{2}$ & df & $p$ & Nagelkerke $R^{2}$ & Accuracy (\%) \\
\hline Block 1 & 33.70 & 4 & $<.001$ & .107 & 62.7 \\
\hline Block 2 & 11.70 & 1 & $<.001$ & .142 & 63.0 \\
\hline Block 3 & 62.21 & 1 & $<.001$ & .312 & 72.1 \\
\hline
\end{tabular}

Notes: ${ }^{1} p$ value based on 2,000 bootstrapped samples.

DV: Higher-risk drinking on AUDIT-C (1 = Positive for higher-risk consumption; 0 = Negative for higher-risk consumption). Hosmer and Lemeshow test: $\chi^{2}(8)=6.78 . p=.56$.

Comparison to null model at Block $3: \chi^{2}(5)=107.61, p<.001$.

That the association between user-created alcohol promotion and higher-risk drinking was best understood when awareness and participation was measured cumulatively (i.e. not the influence of individual channels) is consistent with research which has found a similar cumulative effect for user-created alcohol promotion on social networking sites (Stoddard, Bauermeister, Gordon-Messer, Johns, \& Zimmerman, 2012; Westgate, Neighbors, Heppner, Jahn, \& Lindgren, 2014). The results broaden understanding by suggesting that cumulative exposure includes channels beyond social networking websites (e.g. video sharing, forums, and apps). The results also show that participation had a stronger association with alcohol use than awareness. Nonetheless, it remains plausible that those who do not participate may still be aware of user-created alcohol promotion, which the results suggest is also still associated with higher-risk consumption. That a cumulative effect and stronger association of participation are both trends that are also observed for commercial alcohol marketing (Gordon et al., 2010; Lin et al., 2012) suggests the way that user-created promotion influences consumption has similarities to its commercial counterpart. Future research should therefore consider how other marketing concepts, for instance message interpretation (Austin \& Knaus, 2000), may aid understanding of the influence that usercreated promotion has on attitudes and behaviour.

\section{Limitations}

The study has several limitations which inform how the findings should be interpreted. The study was crosssectional and the findings are open to the possibility that existing higher-risk drinking may fuel interest in usercreated alcohol promotion and not the other way around. A causal relationship between user-created alcohol promotion and consumption is supported by longitudinal research on the related topic of commercial digital marketing (de Bruijn et al., 2016; Gordon et al., 2010) and by longitudinal surveys and controlled experimental research into user-created promotion on social networking sites (Boyle et al., 2016; D'Angelo et al., 2014; Litt \& Stock, 2011; Pumper \& Moreno et al., 2013). Further research, however, is needed to explore this effect across the broader range of digital media (e.g. videos and apps). 
The results may also underestimate awareness of, and participation with, user-created alcohol promotion and the association with higher-risk drinking. For example, the measurement tool only provides insight into channellevel awareness and participation. The results therefore do not differentiate between a respondent who had, for example, created and shared many alcohol-related photos compared to someone who had only created and shared a few. The forms of user-created alcohol promotion assessed were also not exhaustive and did not consider convergent or novel forms of promotion such as social entertainment websites (Finnis, 2015) or references on dating applications (Conway, 2015). Furthermore, it is also possible that some content may not have been recognised by participants as promoting alcohol (e.g. photographs of friends holding drinks at a house party) which may have led to under-reporting, or that some channels may have overlapped with each other, which may have led to over-reporting (e.g. some social media statuses can contain photographs or videos).

Research has also suggested that young adults do not always recognise commercial alcohol marketing (Lyons et al., 2014; Niland, McCreanor, Lyons, \& Griffin, 2017). Given the close and interacting relationship between the two (Figure 1) it is therefore possible some participants may have unintentionally reported exposure to content they assumed to be user-created alcohol promotion without recognising that it was in fact commercial marketing (e.g. viral videos shared by peers). This issue is compounded by the fact that the many digital channels are likely to contain a mixture of both marketing and user-created promotion (e.g. microblogging, smartphone apps and video sharing websites). As measurement of awareness and participation only had dichotomous responses, it is possible that a 'do not know' option may have identified when a participation could not be sure they had been exposed to user-created promotion or whether they could not be sure if what they had seen had commercial marketing origins.

Finally, the small and self-selected sample informs how the findings can be interpreted. Due to the recruitment strategies used most participants are likely to have been undergraduate university students in full-time education. Although recruitment through social media and an online forum may have also captured participants who were not students (e.g. those who had graduated) the results are still not representative of all young adults in the UK. Recruitment through online channels may have also positively skewed the reported exposure. For instance, those recruited through a digital forum and social media are likely to have been more actively engaged in digital activities, while the opt-in process for all forms of recruitment may mean that only those with an interest in user-created promotion or alcohol chose to participate. Furthermore, as some participants were recruited from an undergraduate psychology course, the possibility of response bias, because of familiarity with research methods, cannot be rejected. There was also a sizable gender skew as more females chose to participate.

\section{Practical Applications and Future Research}

The results highlight several practical applications that may be worthy of future research. First, as there also appears to be an association between commercial digital marketing and alcohol use in young people (de Bruijn et al., 2016; Critchlow, Moodie, Bauld, Bonner, \& Hastings, 2016; Gordon et al., 2010), future research should consider the similarities and differences between marketing and user-created alcohol promotion, the combined effect on drinking, and whether one form of content has a stronger association with alcohol-related outcomes. Second, future research should explore which psychological processes underpin the relationship between usercreated alcohol promotion and consumption, such as outcome expectancies, drinking motives, and perceived social norms. Third, future research should consider novel methods of measuring exposure to user-created alcohol promotion and the association with consumption. Examples from research into commercial marketing include momentary assessment of exposure through handheld devices (Collins et al., 2016) and use of eyetracking to evaluate attentional bias (Thompson \& Fulton, 2007). Fourth, as research also suggests that usercreated alcohol promotion can contain both positive and negative depictions of alcohol (Primark et al., 2015) future research should consider whether different ways of framing consumption influences higher-risk drinking in different ways. Finally, research should further explore whether user-created content could also be used to promote lower-risk drinking (Moreno et al., 2016; Westgate \& Holliday, 2016). A real-world example of this is Hello Sunday Morning, a social marketing campaign which merges an individual's public and private realm by asking them to monitor their own consumption (e.g. using an app) and share with others the activities they 
participate in on hangover-free days, using a bespoke social networking website (Carah, Meurk, \& Hall, 2015; Pennay, MacLean, \& Rankin, 2016).

\section{Conclusion}

This study extends understanding of user-created alcohol promotion in three ways. First, it has provided the first formal definition of user-created alcohol promotion, demonstrated that this definition can be used to measure exposure and the association with higher-risk drinking, and highlighted the relationship that such content has with commercial marketing. Second, it has provided evidence that young adults in the UK are aware of, and have participated with, a range of content which meets this definition of user-created alcohol promotion, even outside of the narrowly defined areas of social networking websites which have dominated early research. Finally, by demonstrating an association between user-created alcohol promotion and higher-risk drinking, the results extend understanding by suggesting this effect is cumulative, includes exposure to content beyond social media, and has several similarities with the influence of commercial digital marketing. This study, however, only has only provided a snapshot of awareness and participation with online media, in a small and selected sample with which had a high gender skew. The results provide therefore several avenues for future research.

\section{Acknowledgements}

This research was funded by The Salvation Army (TSA). The authors pay thanks to ALOVE! This group represent TSA for the new generation and are responsible for the implementing the national youth work strategy by delivering worship, discipleship, mission, and social action. The authors also thank TSA's Scottish Drug and Alcohol Strategy Group and the Centre for Applied Research and Assessment in Adolescent and Child Wellbeing at the University of Roehampton, particularly Dr. Catherine Gilvarry and Prof. Cecilia Essau for their input in early stages of project development. The authors thank the three reviewers for their helpful and constructive comments on the manuscript.

\section{References}

Arnhold, U. (2010). User generated branding: Integrating user generated content into brand management. Bremen: Springer Gabler Research.

Atkinson, A., Elliot, G., Bellis, M., \& Sumnall, H. (2011). Young people, alcohol and the media. York, UK: Joseph Roundtree Foundation. Retrieved from: https://www.jrf.org.uk/report/young-people-alcohol-and-media

Atkinson, A. M., Ross, K. M., Begley, E., \& Sumnall, H. (2014). Constructing alcohol identities: The role of social network sites (SNS) in young peoples' drinking cultures. (Alcohol insight number 119). London, UK: Alcohol Research UK. Retrieved from: http://alcoholresearchuk.org/news/constructing-alcohol-identities-the-role-of-socialnetwork-sites-sns-in-young-peoples-drinking-cultures/

Austin, E.W., \& Knaus, C. (2000). Predicting the potential for risky behavior among those "too young" to drink as the result of appealing advertising. Journal of Health Communication, 5(1), 13-27.

http://dx.doi.org/10.1080/108107300126722

Avery, A., Rae, L., Summit, J., \& Kahn, S. A. (2016). The fire challenge: A case of report and analysis of self-inflicted flame injury posted on social media. Journal of Burn Care and Research, 37, 161-165.

http://dx.doi.org/10.1097/BCR.0000000000000324

Barry, A. R., Chaney, B. H., Stellefson, M. L., \& Dodd, V. (2015). Evaluating the psychometric properties of the AUDIT-C among college students. Journal of Substance Use, 20(1), 1-5.

http://dx.doi.org/10.1177/0047237915596605 
Boyle, S. C., LaBrie, J. W., Froidevaux, N. M., \& Witkovic, Y. D. (2016). Different digital paths to the keg: How exposure to peers' alcohol-related social media content influences drinking among male and female first-year college students. Addictive Behaviours, 57, 21-29. http://dx.doi.org/10.1016/j.addbeh.2016.01.011

Canbrera-Nguyen, E. P., Cavozos-Rehg, P., Krauss, M., Bierut, L. J., \& Moreno, M. A. (2016). Young adults' exposure to alcohol and marijuana related content on Twitter. Journal of Studies on Alcohol and Drugs, 77, 349-353.

http://dx.doi.org/10.15288/jsad.2016.77.349

Captain Morgan. (2015, December 22). What should your \#SquadGoals be for 2016? BuzzFeed. Retrieved from https://www.buzzfeed.com/captainmorganglobal/what-should-your-squadgoals-be-for-

2016?utm_term=.ukxmmkVXa\#.wvAOOoEjw

Carah, N. (2014). Like, comment, share: Alcohol brand activity on Facebook. Deakin West, ACT: Foundation for Alcohol Research and Education. Retrieved from http://fare.org.au/wp-content/uploads/research/Facebook-andalcohol-advertising-report.pdf

Carah, N., Meurk, C., \& Hall, W. (2015). Profiling Hello Sunday Morning: Who are the participants. International Journey of Drug Policy, 26, 214-216. http://dx.doi.org/10.1016/j.drugpo.2014.07.019

Cavavoz-Rehg, P. A., Krauss, M. J., Sowles, S. J., \& Bierut, L. J. (2014). "Hey Everyone, I'm Drunk." An evaluation of drinking-related Twitter chatter. Journal of Studies on Alcohol and Drugs, 76, 635-643.

http://dx.doi.org/10.15288/jsad.2015.76.635

Collins, R. K, Martino, S. C., Kovalchik, S. A., Becker, K. M., Shadel, W. G., \& D'Amico, E. J. (2016). Alcohol advertising exposure among middle school-age youth: An assessment across all media and venues. Journal of Studies on Alcohol and Drugs, 77, 384-392. http://dx.doi.org/10.15288/jsad.2016.77.384

Committee of Advertising Practitioners. (2015). The CAP Code: The UK Code of non-broadcast advertising and direct \& promotional marketing. London: Committee of Advertising Practitioners.

Conway, E. (2015, April 8). Tinder and sobriety are incompatible. The Guardian. Retrieved from:

http://www.theguardian.com/commentisfree/2015/apr/08/tinder-dating-sobriety-incompatible-drinking-alcoholdating

Critchlow, N., Moodie, C., Bauld, L., Bonner, A., \& Hastings, G. (2016). Awareness of, and participation with, digital alcohol marketing, and the association with frequency of high episodic drinking among young adults. Drugs:

Education, Prevention, and Policy, 23, 328-336. http://dx.doi.org/10.3109/09687637.2015.1119247

D'Angelo, J., Kerr, B., \& Moreno, M.A. (2014). Facebook displays as predictors of binge drinking: From the virtual to the visceral. Bulletin of Science, Technology and Society, 34, 159-169.

http://dx.doi.org/10.1177/0270467615584044

Dawson, D. A., Smith, S. M., Saha, T. D., Rubinsky, A. D., \& Grant, B. F. (2012). Comparative performance of the AUDIT-C in screening for DSM-IV and DSM-5 consumption disorders. Drug and Alcohol Dependence, 126, 384-388. http://dx.doi.org/10.1016/j.drugalcdep.2012.05.029

de Bruijn, A., Tanghe, J., de Leeuw, R., Engels, R., Anderson, P., Beccaria, F., Bujalski, M., Celata, C., Gosselt, J., Schreckenberg, D., Slodownik, L., Wothge, J., van Dalen, W. (2016). European longitudinal study on the relationship between adolescents' alcohol marketing exposure and alcohol use. Addiction, 111, 1774-1784. http://dx.doi.org/ 10.1111/add.13455

DeMartini, K. S. \& Carey, K. B. (2012). Optimizing the Use of the AUDIT for Alcohol Screening in College Students. Psychological Assessment, 24, 954-963. http://dx.doi.org/10.1037/a0028519 
Department of Health. (2013). NHS health check programme: Best practice guidance. London, UK: Department for Health. Retrieved from: www.healthcheck.nhs.uk/document.php?o=456

Facebook. (2015). Facebook Q2 2015 results. Retrieved from: http://files.shareholder.com/downloads/AMDANJ5DZ/0x0x842064/619A417E-5E3E-496C-B125-987FA25A0570/FB_Q215EarningsSlides.pdf

Finnis, A. (2015, May 25). 23 times Tumblr perfectly summed up being drunk. Retrieved from: http://www.buzzfeed.com/alexfinnis/times-tumblr-perfectly-summed-up-being-drunk\#.bh8WzVJMAb

Fournier, A. K., \& Clarke, S. (2011). Do college students use Facebook to communicate about alcohol? An analysis of student profile pages. Cyberpsychology: Journal of Psychosocial Research on Cyberspace, 5(2), article 2. Retrieved from https://cyberpsychology.eu/article/view/4246/3292

Foxcroft, D. R., Smith, L., Thomas, H., \& Howcutt, S. (2015). Accuracy of Alcohol Use Disorders Identification Test (AUDIT) for detecting problem drinking in 18-35 year-olds in England: Method comparison study. Alcohol and Alcoholism, 50, 244-250. http://dx.doi.org/10.1093/alcalc/agu095

Gell, L., Ally, A., Buykx, P., Hope, A., \& Meier, P. (2015). Alcohol's harm to others: An Institute of Alcohol Studies Report. London, UK: Institute for Alcohol Studies. Retrieved from http://www.ias.org.uk/uploads/pdf/IAS\%20reports/rp18072015.pdf

Glassman, T. (2012). Implications for college students posting pictures of themselves drinking alcohol on Facebook. Journal of Alcohol and Drug Education, 56, 38-58.

Gordon, R., MacKintosh, A. M., \& Moodie, C. (2010). The impact of alcohol marketing on youth drinking behaviour: A two-stage cohort study. Alcohol and Alcoholism, 45, 470-480. http://dx.doi.org/10.1093/alcalc/agq047

Griffiths, R., \& Casswell, S. (2010). Intoxigenic digital spaces? Youth, social networking sites and alcohol marketing. Drug and Alcohol Review, 29, 525-530. http://dx.doi.org/ 10.1111/j.1465-3362.2010.00178.x

Grube, J. W. (2004). Alcohol in the media: Drinking portrayals, alcohol advertising, and alcohol consumption among youth. In R. J. Bonnie \& M. E. O'Connell (Eds), Reducing underage drinking: A collective responsibility (pp. 597624). Washington, DC: The National Academies Press.

Gupta, H., Pettigrew, S., Lam, T., \& Tait, R. J. (2016). A systematic review of the impact of exposure to internetbased alcohol-related content on young people's alcohol use behaviours. Alcohol and Alcoholism, 51, 763-771. http://dx.doi.org/10.1093/alcalc/agw050

Instagram. (2015). Press page. Retrieved from https://www.instagram.com/press/

Internet Society. (2015). Global internet report 2015. Geneva, Switzerland: Internet Society. Retrieved from: http://eu.wiley.com/WileyCDA/WileyTitle/productCd-063122601X.html

Jenkins, H. (2006). Convergence culture: Where old and new media collide. New York, NY: New York University Press.

Kaplan, A. M., \& Haenlein, M. (2010). Users of the world, unite! The challenges and opportunities of social media. Business Horizons 53, 59-68. http://dx.doi.org/ 10.1016/j.bushor.2009.09.003

Klettke, B., Hallford, D. J., \& Mellor, D. J. (2014). Sexting prevalence and correlates: A systematic literature review. Clinical Psychology Review, 34, 44-53. http://dx.doi.org/ 10.1016/j.cpr.2013.10.007

Lin, E-Y., Caswell, S., You, R. Q., \& Huckle, T. (2012). Engagement with alcohol marketing and early brand allegiance. Addiction Research and Theory, 20, 329-338. http://dx.doi.org/10.3109/16066359.2011.632699 
Litt, D. M. \& Stock, M. L. (2011). Adolescent alcohol-related risk cognitions: The roles of social norms and social networking sites. Psychology of Addictive Behaviours, 25, 708-713. http://dx.doi.org/10.1037/a0024226

Livingstone, S. (2003). The changing nature of audiences: From the mass audience to the interactive media user. In A. N. Valdivia (Ed.), A companion to media studies (pp. 337-359). London, UK: Wiley-Blackwell.

Lobstein, T., Landon, J., Thornton, N., \& Jernigan, D. (2016). The commercial use of digital media to market alcohol products: A systematic review. Addiction. Advance online publication.

http://dx.doi.org/10.1111/add.13493

Lyons, A. C., McCreanor, T., Goodwin, I., Moewaka-Barnes, H., O'Carroll A. D., Niland, P., . . Vroman, K. (2014). Flaunting it on Facebook: young adults, drinking cultures and the cult of celebrity. Wellington, NZ: Massey University School of Psychology. Retrieved from:

http://mro.massey.ac.nz/bitstream/handle/10179/5187/DrinkingCulturesReportWeb.pdf?sequence=3\&isAllowed $=\mathrm{y}$

Marczinski, C. A., Hertzenberg, H., Goddard, P., Maloney, S. F., Stamates, A. L., \& O'Connor, K. (2016). Alcoholrelated Facebook activity predicts alcohol use patterns in college students. Addiction, Research and Theory, 24, 398-405. http://dx.doi.org/10.3109/16066359.2016.1146709

Mart, S., Mergendoller, J., \& Simon, M. (2009). Alcohol promotion on Facebook. The Journal of Global Drug Policy and Practice, 3(18), 1-8. Retrieved from:

http://www.globaldrugpolicy.org/Issues/Vol\%203\%20lssue\%203/Alcohol\%20Promotion\%20on\%20Facebook.pdf

McCracken, J. C., \& Macklin, M. C. (1998). The role of brand names and visual cues in enhancing memory for consumer packaged goods. Marketing Letters, 9, 209-226. http://dx.doi.org/ 10.1023/A:1007965117170

McKenzie, P. J., Burkell, S., Wong, L., Whippey, C., Trowso, S. E., \& McNally, M. (2012). User-created online content 1: Overview, current state and context. First Monday, 17(6-4), Article 1. http://dx.doi.org/10.5210/fm.v17i6.3912

McNally, M. B., Trosow, S. E., Wong, L., Whippey, C., Burkell, J., \& McKenzie, P. J. (2012). User-created online content 2: Policy implications. First Monday, 17(6-4), article 2. http://dx.doi.org/10.5210/fm.v17i6.3913

Moreno, M. A., Cox, E. D., Young, H. N., \& Haaland, W. (2015). Underage college students' alcohol displays on Facebook and real-time alcohol behaviors. Journal of Adolescent Health, 56, 646-651.

http://dx.doi.org/10.1016/j.jadohealth.2015.02.020

Moreno, M. A., D'Angelo, J., \& Whitehill, J. (2016). Social media and alcohol: Summary of research, intervention ideas and future study directions. Media and Communications, 4(3), 50-59.

http://dx.doi.org/10.17645/mac.v4i3.529

Moreno, M. A., Briner, L. R., Williams, A., Brockman, L., Walker, L., \& Christakis, D. A. (2009). Real use or "real cool": Adolescents speak out about displayed alcohol references on social networking websites. Journal of Adolescent Health, 45, 420-422. http://dx.doi.org/10.1016/j.jadohealth.2009.04.015

Moreno, M. A., Parks, M., \& Richardson, L. P. (2007). What are adolescents showing the world about their health risk behaviours on MySpace? Medscape General Medicine, 9(4), 9-15. Retrieved from:

http://www.ncbi.nlm.nih.gov/pubmed/18311359

Morgan, E. M., Snelson, C., \& Elison-Bowers, P. (2010). Image and video disclosure of substance use on social media websites. Computers in Human Behavior, 26, 1405-1411. http://dx.doi.org/10.1016/j.chb.2010.04.017

Moss, A. C., Spada, M. M., Harkin, J., Albery, I. P., Rycroft, N., \& Nikcevic, A. V. (2015). Neknomination: Predictors in a sample of UK university students. Addictive Behaviors Reports, 1, 73-75.

http://dx.doi.org/10.1016/j.abrep.2015.05.003 
Neknominate. (n.d.). In Facebook [Community]. Retrieved June, 30, 2015 from

https://www.facebook.com/neknominate2014/?fref=ts

Newbury-Birch, D., Walker, J. Avery, L., Beyer, F., Brown, N., Jackson, C. A., McGovern, R., Kaner, E., Gilvarry, E., \& Stewart, S. (2009). Impact of alcohol consumption on young people: A systematic review of published reviews. Newcastle, UK: Newcastle University.

Niland, P., Lyons, A. C., Goodwin, I., \& Hutton, F. (2014). 'See it doesn't look does it?': Young adults airbrushed drinking practices on Facebook. Psychology and Health, 29, 877-895.

http://dx.doi.org/10.1080/08870446.2014.893345

Niland, P., McCreanor, T., Lyons, A. C., \& Griffin, C. (2017). Alcohol marketing on social media: Young adults engage with alcohol marketing on Facebook. Addiction Research and Theory, 25, 273-284.

http://dx.doi.org/10.1080/16066359.2016.1245293

Norman, J., Grace, S., \& Lloyd, C. (2014). Legal high groups on the internet: The creation of new organised deviant groups? Drugs: Education, Prevention and Policy, 21(1), 14-23. http://dx.doi.org/10.3109/09687637.2013.769500

OFCOM. (2015a). Adults' media use and attitudes report, 2015. London, UK: OFCOM. Retrieved from:

http://stakeholders.ofcom.org.uk/market-data-research/other/research-publications/adults/media-lit-10years/

OFCOM. (2015b). Children and parents: Media use and attitudes report, 2015. London, UK: OFCOM. Retrieved from: http://stakeholders.ofcom.org.uk/market-data-research/other/research-publications/childrens/children-parentsnov-15/

Office for National Statistics. (2015a). Statistical bulletin: Internet users, 2015. London: Office for National Statistics. Retrieved from:

http://www.ons.gov.uk/businessindustryandtrade/itandinternetindustry/bulletins/internetusers/2015

Office for National Statistics. (2015b). Adult drinking habits in Great Britain, 2013. London, UK: Office for National Statistics. Retrieved from:

http://www.ons.gov.uk/peoplepopulationandcommunity/healthandsocialcare/healthandlifeexpectancies/compe ndium/opinionsandlifestylesurvey/2015-03-19/adultdrinkinghabitsingreatbritain2013

Office for National Statistics. (2016). Statistics on alcohol: England 2016. London, UK: Office for National Statistics. Retrieved from: http://content.digital.nhs.uk/catalogue/PUB20999/alc-eng-2016-rep.pdf

Organisation for Economic Co-operation and Development. (2007). Participative web: User-created promotion. OECD. Retrieved from: http://www.oecd.org/sti/38393115.pdf

Parder, M-L. \& Vihaleem, T. (2015). “...if there's a party, then there's definitely alcohol": Construction of partying practices and abstinence in Estonian youth forums. Nordic Studies on Alcohol and Drugs, 32, 563-578.

http://dx.doi.org/10.1515/nsad-2015-0054

Pennay, A., MacLean, S., \& Rankin, G. (2016). Hello Sunday Morning: Alcohol, (non)consumption and selfhood. International Journey of Drug Policy, 28, 67-75. http://dx.doi.org/10.1016/j.drugpo.2015.10.008 0955-3959

Perry, F. (2015, October 6). Can we guess what kind of drunk you are? BuzzFeed. Retrieved from: https://www.buzzfeed.com/floperry/can-we-guess-what-kind-of-drunk-you-

are?utm_term=.nhQRRV9bY\#.jgRmmEbAy

Primack, B. A., Colditz, J. B., Pang, K. C., \& Jackson, K. M. (2015). Portrayal of alcohol intoxication on YouTube. Alcoholism: Clinical and Experimental Research, 39, 496-503. http://dx.doi.org/10.1111/acer.12640 
Pumper, A., \& Moreno, M. A. (2013). Identifying high-risk alcohol users among first-year college students: Attitude, intention, and Facebook. Journal of Alcoholism and Drug Dependence, 1(5), 1-5.

http://dx.doi.org/10.4172/2329-6488.1000128

Ridout, B. (2016). Facebook, social media and its application to problem drinking among college students. Current Opinion in Psychology, 9, 83-87. http://dx.doi.org/10.1016/j.copsyc.2015.12.005

Ridout, B., Campbell, A., \& Ellis, L. (2012). 'Off your Face(book)': Alcohol in online social identity construction and its relation to problem drinking in university students. Drug and Alcohol Review, 31(1), 20-26.

http://dx.doi.org/10.1111/j.1465-3362.2010.00277.x

Statistica. (2015). Distribution of internet users worldwide as of November 2014, by age group. Retrieved from: http://www.statista.com/statistics/272365/age-distribution-of-internet-users-worldwide/

Statistics Brain. (2015). YouTube Statistics. Retrieved from http://www.statisticbrain.com/youtube-statistics/

Stoddard, S. A., Bauermeister, J. E., Gordon-Messer, D., Johns, M., \& Zimmerman, M. A. (2012). Permissive norms and young adults' alcohol and marijuana use: The role of online communities. Journal of Studies on Alcohol and Drugs, 73, 968-975. http://dx.doi.org/10.15288/jsad.2012.73.968

StreamDaily. (2014, June $23^{\text {rd }}$ ). Under the influence of....Alcohol! Stream Daily. Retrieved from: http://streamdaily.tv/2014/06/23/under-the-influence-of-alcohol/\#

Thompson, S. R., \& Fulton, K. (2007). Adolescents' attention to responsibility messages in magazine alcohol advertisements: An eye-tracking approach. Journal of Adolescent Health, 41(1, 27-34.

http://dx.doi.org/10.1016/j.jadohealth.2007.02.014

van Dijck, J. (2009). Users like you? Theorizing agency in user-generated content. Media, Culture and Society, 31 , 41-58. http://dx.doi.org/10.1177/0163443708098245

van Dijck, J. (2012). Facebook as a tool for producing sociality and connectivity. Television and New Media, 13, 160176. http://dx.doi.org/10.1177/1527476411415291

van Hoof, J. J., Bekkers, J., \& van Vuuren, M. (2014). “Son, you're smoking on Facebook!" College students' disclosure on social networking sites as indicators of real-life risk behaviours. Computers in Human Behaviour, 34, 249-257. http://dx.doi.org/ 10.1016/j.chb.2014.02.008

Viral Videos Today. (2014, January 16). Neknomination Neknominate Compilation \#1 - January 2014 - Latest Social Media Trend [YouTube video file]. Retrieved from: https://www.youtube.com/watch?v=6ZmQIR03J1g

Weaver, E. R., Horyniak, D. R., Jenkinson, R., Dietze, P., \& Lim, M. S. C. (2013). "Let's get wasted" and other apps: Characteristics, acceptability and use of alcohol-related smartphone application. JMIR MHealth and UHealth, 1(1), e9. http://dx.doi.org/ 10.2196/mhealth.2709

Westgate, E. C., \& Holliday, J. (2016). Identity, influence and intervention: The roles of social media in alcohol use. Current Opinion in Psychology, 9, 27-23. http://dx.doi.org/10.1016/j.copsyc.2015.10.014

Westgate, E. C., Neighbors, C., Heppner, H., Jahn, S., \& Lindgren, K. P. (2014). "I will take a shot for every 'like' I get on this status": posting alcohol-related Facebook content is linked to drinking outcomes. Journal of Studies on Alcohol and Drugs, 75, 390-398. http://dx.doi.org/10.15288/jsad.2014.75.390

Wombacher, K., Reno, J. E., \& Veil, S. R. (2016). NekNominate: Social norms, social media, and binge drinking. Health Communication. Advance online publication. http://dx.doi.org/10.1080/10410236.2016.1146567 
World Health Organisation. (2014). Global status report on alcohol and health 2014. Geneva, Switzerland: World Health Organisation. Retrieved from:

http://apps.who.int/iris/bitstream/10665/112736/1/9789240692763_eng.pdf

Zonfrillo, M. R., Arbogast, K., \& Fien, J. (2014). The knockout game: Recreational assault and traumatic brain injury. The Lancet, 386, 513-514. http://dx.doi.org/10.1016/S0140-6736(14)60184-7

Zonfrillo, M. R., \& Osterhoudt, K. C. (2014). Neknominate: A deadly, social media-based drinking dare. Clinical Paediatrics, 53(12), 1215. http://dx.doi.org/ 10.1177/0009922814536265

\section{Correspondence to:}

Nathan Critchlow

G10, Pathfoot Building

Institute for Social Marketing

University of Stirling

Stirling

Scotland, FK9 4LA

United Kingdom

E-mail: nathan.critchlow(at)stir.ac.uk

\section{About authors}

Nathan Critchlow is a postgraduate researcher at the Institute for Social Marketing, University of Stirling. His main research interests relate to alcohol, particularly marketing and media influence.

Crawford Moodie is a senior research fellow at the Centre for Tobacco Control Research, Institute for Social Marketing, University of Stirling.

Linda Bauld is a Professor of Health Policy, Director of the Institute for Social Marketing, and Dean of Research (Impact) at the University of Stirling. Linda is also the Deputy Director of the UK Centre for Tobacco and Alcohol Studies.

Adrian Bonner is an Honorary Professor in the Faculty of Social Sciences at the University of Stirling. Adrian has also worked with The Salvation Army UK \& Ireland in several capacities, including being a member of the Scottish Drug and Alcohol Strategy Group.

Gerard Hastings is a Professor at the University of Stirling and the Open University and Professeur Associé at the École des Hautes Etudes en Santé Publique in Rennes. His research on the impact of commercial marketing led to the foundation of the Institute for Social Marketing and Centre for Tobacco Control Research.

Editorial record: First submission received on June 12, 2016. Revision received on December 11, 2016 and June 15, 2017. Accepted for publication on June 16, 2017. 